\title{
MARGETTS V. TIMMER ESTATE: \\ The Continuing Development of Canadian Law Relating to Mary Carter Agreements
}

\author{
Barbara Billingsley*
}

\section{INTRODUCTION}

In recent years, the litigation of large losses in Canada has been characterized by two apparently opposing trends. First, in order to spread out the liability risk as much as possible, the current practice appears to be to include every conceivable party as a Defendant or Third Party. This approach results in multiple party litigation of unprecedented dimensions and, consequently, almost necessarily slows down the litigation process. Second, in a contrary attempt to speed up the litigation process and to curb legal fees, the current practice favours the settlement of claims prior to trial whenever possible. This trend is reflected in the current interest in various forms of alternate dispute resolution. The simultaneous application of these conflicting trends results in an obvious potential problem for participants in tort actions involving multiple Defendants: what happens where one or more but not all of the Defendants are interested in entering into a pretrial settlement with the Plaintiff? In such a case, how does the Defendant preferring settlement avoid being dragged into trial by the other Defendants and thereby risk an unfavourable result at trial? One possible solution is for this Defendant and the Plaintiff to enter into a "Mary Carter Agreement."

In the writer's opinion, to date Mary Carter Agreements have been underused as a tool for protecting Plaintiffs and Defendants alike from the risks of multi-party litigation. The infrequent use of Mary Carter Agreements is probably attributable to a general uncertainty among lawyers about the validity of these agreements, the effect of these agreements and the legal requirements which must be met in order to make these agreements operative and enforceable. In Margetts v. Timmer Estate, ${ }^{1}$ Justice Dea of the Alberta Court of Queen's Bench goes a long way to clearing up much of the uncertainty about Mary Carter Agreements by providing one of the most comprehensive Canadian decisions directly addressing some of the most common procedural and substantive challenges raised against these agreements. ${ }^{2}$ Justice Dea's decision is

Lecturer, Faculty of Law, University of Alberta.

(1996), 192 A.R. 42, 43 Alta. L.R. (3d) 283 (Q.B.) [hereinafter Margetts cited to A.R.]. This decision is currently scheduled to be heard by the Alberta Court of Appeal in October, 1998. If the appeal proceeds, the Alberta Court of Appeal will have the opportunity of providing the first appeal level ruling on the validity of Mary Carter Agreements in Canada.

2 There have been a number of Canadian court decisions which have made reference to Mary Carter Agreements or which have made procedural rulings in light of the existence of a Mary Carter Agreement. See for example: Zukowski v. Royal Insurance Co. of Canada, [1998] A.J. No. 534 (Q.B.) (QL); Newell v. Mclvor, [1998] S.J. No. 38 (Q.B.) (QL); Jensen v. Guardian Insurance Co. of Canada, [1997] O.J. No. 5034 (Gen. Div.) (QL); Conrad v. Snair (1996), 150 N.S.R. (2d) 214, 1 C.P.C. (4th) 62, (C.A.); Schmieder v. Singh (1996), 46 C.P.C. (3d) 84 (Ont. Ct. (Gen. Div.)); Silver Streak Holdings Ltd. v. Ando Enterprises Ltd., [1995] N.W.T.J. No. 57 (QL) (S.C.); Syncrude Canada v. Canadian Bechtel Ltd. (1994), 149 A.R. 54, 16 Alta. L.R. (3d) 153 (C.A.); Syncrude Canada v. Canadian Bechtel Ltd. (1991), 118 A.R. 162, 80 Alta. L.R. (2d) 98 (Q.B.); 
particularly notable for its findings regarding the disclosure requirements of Mary Carter Agreements and for its recognition of Mary Carter Agreements as legally valid settlement agreements.

\section{What IS A Mary Carter Agreement?}

The potential for using a Mary Carter Agreement arises where a Plaintiff has sued at least two parties as joint and several tortfeasors and where one of the Defendants wants to settle with the Plaintiff but the other does not. The Defendant favouring settlement may not be able to remove himself from the action simply by settling with the Plaintiff because this Defendant is usually also subject to a claim for contribution from the remaining Defendant pursuant to statutory authority. ${ }^{3}$ The contribution claim allows the remaining Defendant to continue to pursue the settling Defendant at trial for any portion of the judgment which is ultimately paid by the remaining Defendant but which the trial court attributes to the liability of the settling Defendant. Accordingly, settling with the Plaintiff alone does not ordinarily offer the settling Defendant any protection against having to pay additional damages as a result of a large liability finding against the settling Defendant at trial. A Mary Carter Agreement attempts to provide this protection by addressing the potential contribution claim of the remaining Defendant within the context of the settlement arrangement between the Plaintiff and the settling Defendant.

Mary Carter Agreements take their name from the American case of Booth v. Mary Carter Paint Co., ${ }^{4}$ which first publicized this type of settlement arrangement. The

Syncrude v. Canadian Bechtel Ltd. (1990), 112 A.R. 131, 77 Alta. L.R. (2d) 328 (Q.B.); Crawford v. Queen's Hotel (London) Ltd., [1989] O.J. No. 704 (S.C.) (QL). Prior to the Margetts case the only Canadian court case to directly address the validity of these agreements was the Ontario Divisional Court's decision in Avis v. Petty (1993), 13 O.R. (3d) 725, 103 D.L.R. (4th) 298 [hereinafter Avis].

3 In Alberta, for example, the statutory right for one Defendant to claim contribution from another Defendant who is a joint tortfeasor is found in s. 2 of the Contributory Negligence Act, R.S.A. 1980, c. C-23 and s. 3 of the Joint Tort-Feasors Act, R.S.A. 1980, c. T-6. The combined effect of these sections is to allow a Plaintiff who obtains a judgment against multiple Defendants in a tort action to recover the whole amount of his loss from any Defendant (as long as that Defendant has been found liable to some degree) and to allow any Defendant who pays the Plaintiff more than the portion of that Defendant's liability to recover from the other Defendants the amounts reflecting their portion of liability. In practice, this means that as soon as a Plaintiff sues two or more Defendants, the Defendants generally issue cross-claims for contribution against one another. Although the pleadings filed for the cross-claims generally seek "contribution and indemnity," where the cross-claims are founded solely on the statutory provisions noted above, the claims are really for contribution only. A true claim for indemnity by one Defendant against another would not be based on the statutory provisions but would arise from an independent duty of care allegedly owed by one Defendant to another in either contract or tort. In contrast, a contribution claim based on the statutory provisions is based on a duty of care which each Defendant is alleged to have owed to the Plaintiff. 202 So. 2 d 8 (Fla. App. 1967) [hereinafter Booth]. 
original Mary Carter Agreement, as depicted in the Booth case, has been described as including four basic elements: ${ }^{5}$

(1) it guarantees the Plaintiff a minimum recovery from the settling Defendant and caps the exposure of the settling Defendant to an agreed upon amount;

(2) it keeps the settling Defendant in the lawsuit;

(3) it decreases the settling Defendant's liability in direct proportion to any increase in the non-settling Defendant's liability as determined by the Court;

(4) its terms are kept secret from the non-settling parties. ${ }^{6}$

While such an agreement does not remove the settling Defendant from the action, it does remove the settling Defendant's liability risks at trial. By the terms of the agreement, the settling Defendant will never be liable to the Plaintiff for more than the agreed upon portion of the Plaintiff's damages. ${ }^{7}$ In exchange, the Plaintiff is guaranteed recovery of a predetermined amount regardless of the liability findings at trial.

By capping the settling Defendant's financial exposure and guaranteeing the Plaintiff a minimum recovery, a traditional Mary Carter agreement necessarily affects the goals and strategies of its signatories both at trial and during pretrial litigation. In order to obtain the maximum overall recovery possible, the Plaintiff's focus shifts from maximizing the liability of all Defendants to maximizing the liability of the non-settling Defendant. In order to minimize its ultimate payment to the Plaintiff, the settling Defendant's focus also shifts from limiting its own liability to maximizing the Plaintiff's damages and the non-settling Defendant's liability. These shifts in the Plaintiff's and the settling Defendant's objectives may result in new litigation strategies, including, for example:

Avis, supra note 2 at 304-305.

Another pre-trial settlement arrangement which is often confused with a Mary Carter Agreement is the "Pierringer Agreement." A Pierringer Agreement, originating from the American case of Pierringer v. Hoger 124 N.W.2d 106 (Wis. 1963), differs from a true Mary Carter Agreement in that it is designed to completely remove the settling party from the litigation. In a Pierringer Agreement, the settling party pays the Plaintiff a set amount in full satisfaction of the Plaintiff's claim against it and the Plaintiff discontinues its action against the settling Defendant. The Plaintiff continues its action against the non-settling Defendants but promises the settling Defendant that it will not pursue the remaining Defendants for any portion of liability which a court assesses against the settling Defendant. (Like a Mary Carter Agreement, however, a Pierringer Agreement can only protect the settling Defendant from a contribution claim by the remaining Defendants if the contribution claim does not involve a true indemnity claim based on a contractual or tortious duty of care owed by the settling Defendant directly to the non-settling Defendants: See supra note 3).

6 The requirement of secrecy inherent in the original Mary Carter Agreement has been questioned by many American Courts and has been flatly rejected by Canadian law. In fact, Canadian law imposes a positive obligation of disclosure upon the parties entering into a Mary Carter Agreement. The elements of this disclosure obligation are considered in detail later in this article. The settling Defendant is thereby also implicitly protected against any contribution claim brought by the non-settling Defendant. 
- $\quad$ the settling Defendant's abandonment of contributory negligence or assumption of risk arguments against the Plaintiff;

- $\quad$ the settling Defendant's admission of liability;

- a "friendly" cross-examination of the Plaintiff by the settling Defendant's counsel or vice versa. ${ }^{8}$

\section{VARIATIONS ON A THEME - The Agreement in the Margetts CaSe}

The settlement agreements before the Court in the Margetts case did not contain all of the elements of the original Mary Carter agreement as conceived in the Booth case. Nevertheless, the agreements in Margetts were similar to the original Mary Carter Agreement in that they allowed one Defendant to achieve a settlement with the Plaintiff by structuring the settlement arrangements in a manner designed to cap the settling Defendant's liability exposure and to protect the settling Defendant from a contribution claim by the non-settling Defendant. Accordingly, the agreements considered in Margetts were "in the nature of" Mary Carter Agreements.

Margetts v. Timmer Estate was one of fifteen actions arising out of one motor vehicle accident. Most of the actions, including the Margetts action and an action brought by the Formanski family, consisted of personal injury claims alleging negligence against the Defendants Timmer Estate and the Province of Alberta. In June and July of 1994, the Plaintiffs in the Margetts and the Formanski actions entered into settlement discussions with the Province. These discussions led to interim settlement agreements being signed in September, 1994 and final settlement agreements being signed in November 1995. The settlement agreements were between the Margetts and Formanski Plaintiffs and the Crown (the settling Defendant) and didn't involve the Defendant Timmer Estate (the non-settling Defendant). ${ }^{10}$ In November 1995, the Crown brought a motion to have these agreements approved by the Court.

The fundamental terms of the agreements entered into in the Margetts and the Formanski actions were identical in each action and, in summary, provided that: ${ }^{11}$

1. without any admission of liability, the settling Defendant would pay the Plaintiffs a set sum of money as compensation for their damages;

2. the settling Defendant would be at liberty to pursue the Plaintiffs' actions arising from the accident as against the non-settling Defendant;

$8 \quad$ P.M. Iacono, Q.C. \& S. Liquornik, “"Mary Carter' Revisited” (1994) 4 C.I.L.R. 289 at 293-94.

$9 \quad$ Supra note 1 at 46 . Note that, notwithstanding the four elements of a Mary Carter Agreement noted by the Court in Avis, supra note 2, it appears to be commonly accepted that Mary Carter Agreements may take a variety of forms, limited only by the creativity of the counsel involved. Technically, the settlement agreements were drafted to also include and bind the casualty insurers of the settling Defendants.

11 See supra note 1 at $47-50$, for the verbatim wording of the Agreements. 
3. the settling Defendant would be at liberty to pursue its own claims for contribution and indemnity as against the non-settling Defendant;

4. the Plaintiffs would hold harmless the settling Defendant against any claims for contribution by the non-settling Defendant, meaning that the non-settling Defendant would only be pursued by or on behalf of the Plaintiff on the basis of several, rather than joint and several, liability.

5. henceforth any legal costs incurred by the Plaintiffs in prosecuting their claims against the non-settling Defendant would be paid by the settling Defendant;

6. the settling Defendant would hold harmless the Plaintiffs against any costs awarded against the Plaintiffs in favour of the non-settling Defendant;

7. any finding of liability at trial against the non-settling Defendant or any award of costs against the non-settling Defendant would be applied for the sole and exclusive benefit of the settling Defendant.

The overall effect of these terms is that the settling Defendant pays the Plaintiffs a certain sum in exchange for the Plaintiffs agreeing not to pursue the settling Defendant and providing the settling Defendant with the full benefit of any claim the Plaintiffs or the settling Defendant may have against the non-settling Defendant. The Plaintiffs are therefore spared any risk involved in litigating the matter further. The settling Defendant in turn is provided with a guarantee that it will never have to pay damages greater than the amount agreed to in the settlement documents regardless of the degree of liability which a court might ultimately attribute to the settling Defendant. Critical to this guarantee is the Plaintiffs' promise to hold harmless the settling Defendant against any contribution claim by the non-settling Defendant. By ensuring that the Plaintiff will never try to recover damages from the non-settling Defendant in excess of the degree of liability which a court attributes to the non-settling Defendant, this promise negates any contribution claim which the non-settling Defendant might otherwise have against the settling Defendant. Accordingly, the settling Defendant does not need to worry about ever having to respond to a contribution claim made by the non-settling Defendant. On the other hand, the non-settling Defendant remains responsible for paying the proportion of damages commensurate with any liability finding made against it at trial.

By allowing the settling Defendant to pursue the non-settling Defendant for both the Plaintiffs' claim and the settling Defendant's own contribution claim, this agreement also guarantees that the settling Defendant will recover some or all of the money it paid to settle the action as long as some portion of liability is assessed against the nonsettling Defendant at trial. Assume, for example, that the settling Defendant paid the Plaintiff $\$ 100.00$ under the agreement and a trial court ultimately quantifies the 
Plaintiff's actual damages at $\$ 1,000.00 .{ }^{12}$ If the court then assesses the non-settling Defendant's liability at 90 percent, the settling Defendant, pursuing the action in the Plaintiff's name, could recover $\$ 900.00$ from the non-settling Defendant. On the other hand, if the trial court sets the non-settling Defendant's liability at 10 percent, the settling Defendant, pursuing the action in the Plaintiffs' name, can still recover $\$ 100.00$ from the non-settling Defendant. Alternatively, if the court finds the non-settling Defendant 100 percent liable, the settling Defendant can recover $\$ 900.00$ by pursuing the action in the Plaintiff's name and stands to recover a further $\$ 100.00$ via its own contribution claim. Finally, even if the court ultimately assesses total damages at less than the settlement sum, the settling Defendant can still recoup some of its settlement monies as long as some portion of liability is attributed to the non-settling Defendant. In order to recover as much money as possible, however, the interest of the settling Defendant lies in maximizing the total damage assessment at trial and in maximizing the degree of liability apportioned against the non-settling Defendant by the trial court. Therefore, the settling Defendant is still taking a risk in agreeing to the settlement. For example, if the court ultimately assesses damages at less than the settlement amount, the settling Defendant will be out of pocket even if the court also finds the non-settling Defendant 100 percent liable. ${ }^{13}$

\section{The Legal Issues Regarding Mary Carter Agreements}

Since the inception of Mary Carter Agreements in the United States, a number of arguments have been raised to challenge the use and validity of these agreements. Most of these arguments arise from the fact that Mary Carter Agreements necessarily change the interests and relationships of the parties involved in an otherwise adversarial process. The main concern is that, by changing the interests of the parties involved in litigation, Mary Carter Agreements have the potential to adversely affect the integrity of the court process. In Margetts, Justice Dea considers several of the most common challenges raised against the use of Mary Carter agreements and ultimately concludes that, if properly employed and monitored by the Courts, Mary Carter Agreements are not a threat to the integrity of the court process and instead can serve as a valuable tool for the promotion and achievement of pretrial settlements.

\section{A. The Procedural Issue: Disclosure}

As previously noted, when originally conceived, Mary Carter Agreements were intended to be secretive arrangements between the Plaintiff and a settling Defendant. In Canada, the courts have been clear in rejecting this secrecy element, establishing instead that a Mary Carter Agreement must be disclosed to all parties to the litigation

12 The figures in this example are entirely ficticious and bear absolutely no relation to the actual numbers that appear in the settlement agreements. As noted later in this article, the real settlement figures were never disclosed to the Court or to any other parties, apart from a voluntary, confidential disclosure of these figures to some insurers involved in the action.

13 Obviously, a key factor involved in arranging a Mary Carter Agreement, then, is the determination of the "correct" settlement figure which takes into account the risks being assumed by the settling parties. This factor is particularly important when, as in this case, the agreement permits the settling Defendant to pursue the Plaintiffs claim against the non-settling Defendant. 
and to the court as soon as the agreement is made. ${ }^{14}$ This requirement has now been adopted into the ethical codes of Canadian lawyers. For example, the Alberta Code of Professional Conduct has been interpreted as providing that: ${ }^{15}$

a lawyer who reaches agreement with some, but not all, of the opposing parties in a negotiation must disclose the agreement to the remaining parties if the lawyer's client intends to continue as a party in the matter. An example is a "Mary Carter" agreement whereby one of the defendants in civil litigation settles with the plaintiff on the basis of a so-called guaranteed verdict. If the plaintiff is successful against the other defendants, the settling defendant's position will be enhanced. To conceal such an agreement would be to mislead the other parties since, by continuing in the matter, the parties who have reached the agreement are representing that their positions are unchanged. In fact, the agreement has altered the respective positions or interests of the parties and the appropriate negotiating strategy will be different as a result. Any agreement having this effect, whether in a litigation context or otherwise, must be disclosed to all parties.

This requirement of prompt disclosure of a Mary Carter Agreement is designed to protect the integrity of the court process by ensuring that the court and all parties to an action are fully aware of the interests being pursued by each litigant. Armed with a complete understanding of the relationships between the parties, the Court can take any steps necessary to ensure that litigation procedures reflect the true relationships and interests of the parties involved. For example, as previously discussed, a Mary Carter Agreement typically changes the settling Defendant's interests from minimizing to maximizing the overall assessment of the Plaintiffs' damages. Once aware of this change in the settling Defendant's interests, the court may limit the settling Defendant's ability to examine the Plaintiffs' witnesses regarding the quantification of damages. The court thereby avoids what would now be a "friendly" cross-examination designed to bolster rather than discredit the Plaintiffs' case.

In the Margetts case, the non-settling Defendant argued that the Mary Carter Agreement had not been properly disclosed and was therefore invalid. Justice Dea responds to this argument by first noting that, as long as proper disclosure of a Mary Carter Agreement is made, the effect the Agreement may have on the relationships between the litigants does not itself threaten the integrity of the court process. He states: ${ }^{16}$

Notwithstanding the eloquent recitation of the changes in the relationships between the settling parties both among themselves and with respect to the non-settling parties to this litigation I am of the view that the risk to the court process and its integrity lies not in these changed relationships but in the risk of the non-settling parties trying to conduct litigation without a full and complete knowledge of the relevant facts. Once, however, all of the litigants and the judge know what the arrangements are and Div.) (QL)); Hudson Bay Mining \& Smelting Co. v. Fluor Daniel Inc. (1997), Man. R. (2d) 214, 10 W.W.R. 622 (Q.B.); Avis, supra note 2; Bodnar v. Home Insurance Co. (1987) 25 C.P.C. (2d) 152 (Ont. S.C.); J.M. Chartrand Realty Ltd. v. Martin, [1981] O.J. No. 739 (Ont. S.C.) (QL).

15 Alberta Code of Professional Conduct, Commentary 1 of Chapter 11. See also Commentary 13 of Chapter 10.

$16 \quad$ Supra note 1 at 51. 
are able to see the true relationships between the various parties the risk of wrongdoing or unfairness or lack of integrity in the system is resolved.

This approach certainly appears to be supported by the preceding Canadian case law dealing with the validity of Mary Carter agreements. ${ }^{17}$

Having thus concluded that Mary Carter Agreements must be disclosed to the court and to other parties to the litigation, Justice Dea then turns to the more difficult question of exactly what this disclosure requirement entails. In particular, when must disclosure be made and what portions of the agreement must be disclosed?

The Mary Carter Agreements before Justice Dea in Margetts had obviously been entered into during the course of pretrial litigation and well in advance of trial. Nevertheless, as already noted, the agreements were signed in an interim form nearly a year before the final agreements were signed and disclosed to the court and the nonsettling Defendant. Accordingly, the non-settling Defendant took the position that disclosure of the settlement arrangements had not been made in a timely fashion. Justice Dea rejected this argument, providing the following reasoning: ${ }^{18}$

I was early concerned that some steps in the proceeding might have been taken by some of the litigants after the early settlement discussions had occurred but prior to disclosure. The evidence is that such did not occur. While immediate disclosure is required when a Mary Carter settlement is made in the course of trial such immediacy does not, it seems to me, become so significant in the pre-trial context unless some prejudice is done to one or more of the non-settling parties. In this case the evidence is that there was no prejudice occasioned by delay in disclosure and no allegation of prejudice.

Indeed, because of the growth of pre-trial and case management procedures of various kinds it is unlikely that settlements of this kind will more and more come to be disclosed, as in this case, long before trial or even before trial dates are set. That is of course the situation in this case where much remains to be done to prepare for trial. In such cases, as aforesaid, immediate disclosure is not as significant as disclosure occurring at trial unless of course there is prejudice. What is needed is a clear understanding that parties have not changed their positions or put themselves at risk in ways that would not have occurred had they been aware of the settlement. I do not think that discussions of settlement between litigants constitutes a settlement that needs to be disclosed but clearly arrangements between counsel to settle may constitute a settlement for these purposes long before written agreements and final details are all committed to writing.

Thus, while Justice Dea clearly recognizes the general need for prompt disclosure, he concludes that, where a Mary Carter Agreement is entered into prior to trial, the notion of "prompt" disclosure requires only that disclosure be made before any steps are taken which could prejudice the interests of the non-settling parties. Resolving the question of prompt disclosure therefore requires a consideration of the evidence in each case where the disclosure issue is raised in order to determine whether, on the facts of the case at bar, any prejudice has occurred. 
The next disclosure issue considered by Justice Dea concerns the thoroughness of the disclosure which was made. The settling Defendants had provided the non-settling Defendants and the Court with copies of both the interim and final Mary Carter Agreements but had blocked out all references to the settlement amounts paid by the settling Defendant to the Plaintiffs. ${ }^{19}$ The non-settling Defendants argued that full disclosure of the agreements required disclosure of the settlement figures.

Prior to the Margetts decision, Avis $^{20}$ served as the Canadian benchmark ruling as to what information must be provided in order to constitute proper disclosure of a Mary Carter Agreement. Taking a pragmatic approach, the court in Avis held that proper disclosure must include all of the terms of a Mary Carter Agreement except for the actual settlement figures. According to Avis, the disclosure of the settlement figures is a matter for the discretion of the court. In Margetts, Justice Dea follows and expands this principle, holding that settlement figures should generally not be disclosed to the trial judge:

There is nothing in a knowledge of quantum arrangements between the settling parties that needs be given to non-settling parties in order to maintain the integrity of the process. Indeed, the giving of such information seems to me to have two undesirable effects. The first is that such disclosure would discourage settlement and that is of course contrary to the general policy of the law. Second is that such knowledge in the trial judge would probably disqualify him from hearing the case. ${ }^{21}$

Thus, while Justice Dea supports the Avis rule that the disclosure of settlement figures is a matter for the court to consider in every individual case, Justice Dea's comments arguably go even further and suggest that the presumption should be against disclosure of the settlement. ${ }^{22}$

Several important disclosure issues were not raised in the Margetts case and therefore remain open. First, given Justice Dea's conclusion that the disclosure requirements were properly met, the case does not comment on what the practical consequences of inadequate disclosure might be. As long as the settling parties still want to abide by their agreement, ordinarily a Court would have no authority to set

9 See supra note 12.

20. Supra note 2.

21 Supra note 1 at 52

22 Note that some American courts have imposed a further requirement that the settlement figure in a Mary Carter Agreement be made in "good faith" in order for the agreement to be legally binding. As stated by D. Hillel, "Mary Carter Agreements: Petty v. Avis Car Inc." (1994) 16 Advocates Quarterly 266 at 269:

Some American courts have imposed a good faith standard as a condition of its validity, requiring that the amount payable by the contracting defendant to the plaintiff be "within the ball park" or an "educated guess" or a "rough approximation" of the probable liability of that defendant to the Plaintiff, with the burden being upon the party objecting to the proposed settlement to prove an absence of good faith.

This requirement of good faith is not considered in Margetts or in any other Canadian cases dealing with Mary Carter Agreements. If, however, the legal presumption is now against disclosure of the settlement figures, it seems unlikely that the requirement of good faith will be adopted into Canadian law. 
aside the settlement agreement. Accordingly, improper disclosure would likely be dealt with via procedural remedies such as imposing a stay on the remaining claims against the non-settling Defendant, declaring a mistrial, or awarding costs against the settling parties to compensate the non-settling Defendant for any prejudice which it has suffered as a result of the non-disclosure. Obviously, a crucial fact to consider in determining which of these remedies is most appropriate in a given case is when in the course of litigation the non-disclosure became apparent.

Second, because the settling parties in Margetts disclosed the settlement agreement to the case management judge and to all of the other litigants, Justice Dea did not consider in detail who must be advised of a Mary Carter agreement in order for the settling parties to properly comply with the disclosure requirement. Generally, Justice Dea appears to support the Avis conclusion that disclosure must be made to the trial judge and to the other parties to the action. However, this finding does not necessarily mean that the Mary Carter Agreement must immediately be brought before a court if the agreement is made well in advance of trial and no case management judge is overseeing the case. In such a circumstance, the interests of justice would apparently be served if disclosure is immediately made to the other litigants but is only disclosed to the court at the commencement of trial. Another question is whether the agreement must be disclosed to a jury if one is trying the case.

Finally, the Margetts decision does not discuss the proper procedure for disclosure of a Mary Carter Agreement. As previously noted, in Margetts, counsel for the settling Defendant brought its own motion to have the court approve the Agreement, or, more precisely, to have the court confirm that the Agreement had been properly disclosed. Is such a motion really required by the rule of disclosure or does the rule simply require the settling parties to inform the judge and the other litigants of the agreement, leaving it to the other litigants or to the court itself to challenge the adequacy of the disclosure? Since the case law to date does not consider this question, at present the practical answer appears to be more a matter of litigation strategy than legal requirement. In a given case, is it more advantageous to be proactive and have a Court confirm proper disclosure of a Mary Carter Agreement or to disclose the agreement to the non-settling parties and wait to see if those parties will challenge the adequacy of the disclosure?

\section{B. SUbSTANTive ISSUes:}

The substantive challenges raised by the non-settling Defendant to the Mary Carter Agreement in the Margetts case are summarized by Justice Dea as follows: ${ }^{23}$

(1) That an assignment of a cause of action sounding in a tort of personal injury is unenforceable and any further activity in the actions in question ought to be dismissed or stayed. 
(2) That, by settling with the defendant Crown as one of two joint tortfeasors, the plaintiffs have released any claims they might have had against the defendant Timmers, the non-settling defendant.

(3) That the defendant Crown may not advance any claim for contribution or indemnity against the defendant Timmers because the defendant Crown is never obligated to pay the settling plaintiffs any amount in excess of the Crown's percentage of blame.

(4) That the Contributory Negligence Act is pled by the defendant Crown to restrict the Crown's liability to the settling plaintiffs to the share of responsibility found by the Court against the Crown.

Initially, each of these arguments appear to question the very use of Mary Carter Agreements. Upon closer examination, however, it is clear that only the first of these arguments has any bearing on the legal validity of Mary Carter Agreements. The first argument suggests that a Mary Carter Agreement which allows the settling Defendant to pursue the personal injury action of the Plaintiff is unenforceable: that such an agreement is contrary to public policy and should therefore result in a stay of the entire action. Obviously this argument calls into question the validity of the agreement itself. In contrast, the remaining three arguments assume the legal validity of the Mary Carter Agreement and instead focus on the possible effects of the agreement on the remaining liability claims. Although Justice Dea addresses each of the arguments individually, he implicitly recognizes the above noted distinction by dealing quite substantively with the first argument and by disposing of the last three arguments relatively briefly, characterizing these latter issues as matters which can only be properly resolved at trial.

\section{Champerty \& MAINTENANCE}

The first substantive argument noted above raises the notion that Mary Carter Agreements are contrary to public policy because they violate the common laws against champerty and maintenance. "Champerty" is "a bargain by a stranger with a party to a suit, by which such third person undertakes to carry on the litigation at his own cost and risk, in consideration of receiving, if successful, a part of the proceeds of subject sought to be recovered." "Maintenance" is "an officious intermeddling in a suit which in no way belongs to one, by maintaining or assisting either party, with money or otherwise, to prosecute or defend it." ${ }^{25}$ Thus, the suggestion made by the nonsettling Defendant in Margetts is that Mary Carter Agreements violate the rules against Champerty and Maintenance because the Agreements essentially assign to the settling Defendant the Plaintiffs' action against the non-settling Defendant. ${ }^{26}$

${ }^{24} \quad$ Black Dict. 5th ed. (St. Paul: West, 1979).

Ibid.

Even where a Mary Carter Agreement does not have the effect of such an assignment, champerty and maintenance arguments are often used to challenge the agreement. The challenge is brought on the basis that a Mary Carter Agreement necessarily gives the settling Defendant an interest in maximizing the Plaintiff's damages and allows the Plaintiff to pursue an action which might have been financially unsustainable without the guaranteed recovery from the settling Defendant. 
In the Margetts case, Justice Dea acknowledges the general public policy served by the legal prohibitions against champerty and maintenance or, more specifically, against the assignment of a personal injury action. Relying heavily upon the reasoning of the British Columbia Court of Appeal in Frederickson v. Insurance Corporation of British Columbia $^{27}$ and the Ontario General Division Court in Avis, ${ }^{28}$ however, Justice Dea notes that the rule against assignment of a personal injury action is subject to exceptions. One such exception indicates that the rules against champerty and maintenance do not and should not apply where the parties assuming the benefits and risks of the Plaintiff's claim are already involved in and at risk in the litigation. $\mathrm{He}$ states:

The facts of this case disclose that the settling defendant has a very real interest in the claims of the plaintiffs and is doing nothing improper by attempting to cap his liability and to show, as in the normal course, his fellow defendant as more responsible. Clearly there is here no purpose of "stirring up litigation and strife." In Fleming's terms there is here "no inter-meddling" for some collateral reason. Here there is a legitimate action by a tortfeasor to use his undoubted right to contract to minimize his financial exposure to the plaintiffs. $^{29}$

Justice Dea's conclusions certainly appear well-founded, particularly when one notes that the Margetts settlement agreement specifically, and Mary Carter Agreements in general have the overall effect of minimizing the claims being pursued by parties in litigation. Thus, far from bringing uninterested parties into litigation (as prohibited by the priniciples of champerty and maintenance), Mary Carter Agreements resolve litigation claims and potentially remove parties from litigation. The bottom line is that a Mary Carter Agreement does not alter the substantive claims being made against the non-settling Defendant.

\section{CONTRIBUtion Claims}

The remaining three substantive challenges put forward by the non-settling Defendant go to the effect of the Mary Carter Agreement: specifically, whether the agreement has the effect of releasing the non-settling Defendant from the Plaintiffs' claim or from the settling Defendant's contribution claim. As noted above, Justice Dea generally concludes that these questions can only be properly answered at trial once the liabilities of the various parties have been determined. Nevertheless, while Justice Dea is summarily dismissive of the last two arguments relating to the settling Defendant's contribution claims, his consideration is more detailed with respect to whether a Mary Carter Agreement necessarily results in a dismissal of a Plaintiff's claim against the non-settling Defendant because of the common law joint tortfeasor rule.

The joint tortfeasor rule states that a Plaintiff who releases one joint tortfeasor from an action automatically releases all joint tortfeasors. If this rule applied to the Margetts case, the Plaintiff, having settled its claim against the Crown, would no longer be able 
to pursue the non-settling Defendant. However, relying primarily upon the reasoning of the British Columbia Court of Appeal in Tucker v. Asleson, ${ }^{30}$ Justice Dea concludes that the joint tortfeasor rule does not apply to the Margetts case. According to Tucker v. Aselson, the joint tortfeasor rule only applies where Defendants are true joint tortfeasors: which is a rare occurrence. The Defendants in Margetts, as in the Tucker case, are more appropriately described as several concurrent tortfeasors whose liability is made joint and several only by virtue of legislation which could not have been intended to have the result achieved by the joint tortfeasor rule. ${ }^{31}$

The reasoning provided in Tucker v. Aselson leads to several other arguments against the use of the joint tortfeasor rule at this stage of the Margetts litigation. First, even if the Defendants in Margetts could be true joint tortfeasors (as opposed to concurrent several tortfeasors as suggested by the Tucker reasoning), a liability trial is the only way of determining whether the Defendants are in fact true joint tortfeasors. Accordingly, any application of the joint tortfeasor rule would be premature until a liability trial is concluded. Second, assuming that the Defendants in Margetts are joint tortfeasors, in order for the joint tortfeasor rule to apply the Mary Carter Agreement would have to "release" the settling Defendant. As Justice Dea notes from the Tucker decision, a mere agreement or covenant to sue someone does not constitute a release:

The rule that a release to one jointly or jointly and severally liable releases the other also prevails in the law of contract; but the judges have there developed the limitation upon the rule that a covenant not to sue one does not discharge the other. A document is read as a covenant not to sue and not as a release if it is worded as a covenant not to sue or if, though worded as a release, it expressly reserves the rights against the other parties liable. This limiting rule has been taken over into the law of tort. ${ }^{32}$

Once again, in order for the joint tortfeasor rule to apply to the Margetts case, it would first be necessary for a court to find that the Mary Carter Agreement constitutes a release as opposed to a mere agreement not to sue. It would appear that such a finding would be difficult to make since the agreement does not remove any of the parties from the litigation. With a release, the party released ordinarily walks away from the lawsuit; this is not the situation in Margetts. Further, while it is a question of fact whether a given Mary Carter Agreement constitutes a release of the settling Defendant, generally speaking the authorities implicitly recognize that a Mary Carter settlement can be achieved without the agreement being a release. For example, in Zukowski v. Royal Insurance Company of Canada, the Alberta Court of Queen's Bench contrasted a Consent Judgment with a Mary Carter Agreement, noting that the former releases a joint tortfeasor while the latter does not:

31 Supra note 1 at 55-56. It is worthy of note that this entire joint tortfeasor question has been done away with in Ontario by virtue of s. 139(1) of the Courts of Justice Act, R.S.O. 1990, c. C-43, s. 139(1) which provides that:

Where two or more persons are jointly liable in respect of the same cause of action, a judgment against or release of one of them does not preclude judgment against any other in the same or a separate proceeding.

32 Supra note 1 at 56, citing Tucker v. Aselson, [1993] 6 W.W.R. 45, 24 B.C.A.C. 253 (C.A.) citing G. Williams, Joint Torts and Contributory Negligence (London: Stevens and Sons, 1951) at 44-45. 
Plaintiffs go to great lengths through arrangements such as Mary Carter Agreements when resolving their claims against one tortfeasor to ensure that they do not proceed to take judgment against that tortfeasor because the effect of that judgment will extinguish the balance of any claim to which the Plaintiff considers it may be entitled against the balance of the tortfeasors. ${ }^{33}$

\section{CONClusions: The Margetts DeCision AND THE FUture of MARY CARTER AGREements}

From a strictly legal perspective, it appears that Justice Dea's basic finding in the Margetts case is sound: that is, with proper disclosure requirements in place, Mary Carter Agreements do not pose a threat to the integrity of the court process. Nevertheless, Justice Dea's decision does not address the larger policy question of whether Mary Carter Agreements should be accepted as part of this province's litigation scheme. This larger question should not be avoided in light of the suggestion by some lawyers that, in jurisdictions where the courts accept Mary Carter Agreements, such agreements will become a crucial legal tool in multi-party litigation. ${ }^{34}$

As noted at the outset of this comment, Alberta courts, lawyers and litigants in recent years have encouraged and promoted the settlement of lawsuits in an effort to minimize court costs and other personal and financial expenses associated with litigation. While Mary Carter Agreements are certainly a form of pre-trial settlement, it is questionable whether they really advance the policy of minimizing litigation or whether they serve primarily as a litigation tool. Unlike more orthodox settlement arrangements, Mary Carter Agreements themselves do not necessarily cut short the trial process or eliminate the number of legal issues the court must resolve. In fact, the primary way that Mary Carter Agreements promote the pre-trial resolution of an action is arguably by putting pressure upon the non-settling parties in an action to enter into a settlement agreement that will resolve the whole claim. In this light, Mary Carter Agreements look more like aggressive litigation strategies than true mechanisms of compromise and accommodation.

There are, however, several responses to the argument that Mary Carter Agreements do not promote directly the policy of settlement. First, assuming that settlement is the policy which should be promoted by Mary Carter Agreements, these agreements may ultimately achieve this result by putting pressure on the non-settling Defendants. If the threat of or the existence of Mary Carter Agreements cause non-settling Defendants to reconsider the fairness or the risks associated with their position, the Agreements provide a valuable service in promoting overall settlement. Moreover, if the fact that Mary Carter Agreements indirectly promote settlement by putting pressure on nonsettling defendants makes the Agreements aggressive litigation tools, these Agreements are certainly not the only litigation techniques which can be characterized in this way. Formal settlement offers, for example, can also be described as litigation techniques which encourage settlement by putting pressure on a party who might otherwise be

33. Supra note 2 at para. 11. See also Iacono \& Liquornik, supra note 8 at 294.

34 L. Chen, "Mary Carter Agreements Newest Settlement Tool" Lawyers Weekly (27 February 1998) 25 . 
unwilling to settle. Second, there are several policy considerations besides settlement which favour the acceptance of Mary Carter Agreements. For example, without the opportunity to enter into a Mary Carter Agreement with a Defendant who wants to settle the claim, a Plaintiff who lacks adequate funds to take the matter to trial may have to abandon its otherwise valid claim against all of the Defendants or may have to accept inadequate and unfair settlement offers from these Defendants. This risk is not immaterial given the length and expense of our current litigation system. Further, given our society's belief in individual rights and autonomy, Mary Carter Agreements are supported by and lend support to the notion of freedom of contract and the idea that a Plaintiff should be able to resolve his or her claim on any basis which does not damage the integrity of the court process.

Overall, it seems that both practical and policy considerations favour the formal acceptance of Mary Carter Agreements into Alberta's litigation landscape. As Justice Dea notes, the court process will not be threatened as long as the courts keep close watch over these Agreements. Further, although we cannot be certain that Mary Carter Agreements always promote complete pre-trial settlements, these Agreements are valuable to litigants as a method of encouraging such settlements. Given the trend toward multi-party litigation, it seems only fair for Plaintiffs and Defendants desiring settlement to have a method of resolving the action between themselves when other Defendants are refusing to resolve the claim prior to trial. 